BMJ Open

Sport \&

Exercise

Medicine

\title{
Acute effects of cold therapy on knee skin surface temperature: gel pack versus ice bag
}

\author{
Matthew Breslin, Patrick Lam, George A C Murrell
}

To cite: Breslin M, Lam P, Murrell GAC. Acute effects of cold therapy on knee skin surface temperature: gel pack versus ice bag. BMJ Open Sport Exerc Med 2015;1: e000037. doi:10.1136/ bmjsem-2015-000037

- Prepublication history for this paper is available online. To view these files please visit the journal online (http://dx.doi.org/10.1136/ bmjsem-2015-000037).

Accepted 1 November 2015

CrossMark

\section{Orthopaedic Research} Institute, St George Hospital, University of New South Wales, Sydney, New South Wales, Australia

Correspondence to Prof George Murrell murrell.g@ori.org.au

\section{ABSTRACT}

Background: To our knowledge there has been no research that has compared the effectiveness of two popular cold therapy modalities applied to healthy human knees, with a surgical dressing, over a $4 \mathrm{~h}$ period.

Hypothesis: To determine whether gel packs are more effective than ice bags at reducing skin surface temperature in humans.

Study design: This was a randomised, repeated measures crossover study, which included nine healthy participants.

Level of evidence: Level 2.

Methods: Two cold therapy modalities-a gel pack (DonJoy-Orthopaedic Pty Ltd, Normanhurst, New South Wales, Australia) and an ice bag (ICE'N'EASY, Bokarina, Queensland, Australia)—were applied on top of a surgical dressing, covering the knee. Each participant randomly received two cold therapy treatments, in separate sessions, at least 4 days apart. Each session utilised the time protocol of $20 \mathrm{~min}$ application on the hour, for $4 \mathrm{~h}$. Skin surface temperature was recorded throughout the session at 1 min intervals.

Results: In the first application, the ice bag $\left(5^{\circ} \mathrm{C} \pm 1.7^{\circ} \mathrm{C}\right)$ was more effective at reducing skin surface temperature $(p<0.04)$ from baseline than the gel pack $\left(4^{\circ} \mathrm{C} \pm 0.9^{\circ} \mathrm{C}\right)$, and had a significantly greater cooling rate $(p<0.02)$. On the subsequent three applications, both modalities were just as effective at reducing skin surface from baseline, and had similar cooling rates.

Conclusions: An ice bag initially was more effective than the gel pack at reducing skin surface temperature of healthy knees, with a surgical dressing. Over a $4 \mathrm{~h}$ period both gel packs and ice bags were just as effective at reducing skin surface temperature and at maintaining these lower temperatures.

\section{BACKGROUND}

Cold therapy is a popular non-pharmacological intervention used following musculoskeletal injuries and many surgical procedures. The primary aim of cold therapy is the removal of heat energy via conduction from the site of injury, in order to facilitate a therapeutic effect. ${ }^{1}$ Cold therapy produces a

\section{Summary box}

- To our knowledge, this is the only study that tested the progressive effect of ice bag and gel pack on the skin surface temperature of healthy participants, with a standard surgical dressing for $4 \mathrm{~h}$.

- In the first application, the ice bag was more effective at reducing skin surface temperature $(p<0.04)$ from baseline than the gel pack, and had a significantly greater cooling rate $(p<0.02)$.

- On the subsequent three applications, both modalities were just as effective at reducing skin surface from baseline, and had similar cooling rates.

number of physiological effects to the human body including a reduction in blood flow, oedema, haemorrhage, ${ }^{2}$ cellular metabolic rate, hypoxia, enzymatic activity and tissue damage. ${ }^{3}$ Cold therapy has also been demonstrated to significantly increase the pain threshold and pain tolerance by reducing nerve conduction velocity and muscle spasm. ${ }^{4}$

Cold therapy application varies with modality, duration and frequency. ${ }^{5-7} \mathrm{~A}$ number of different cold therapy modalities are currently used for the treatment of musculoskeletal trauma, ranging from bags of ice $^{8}$ to electrically powered continuous cold therapy devices. ${ }^{9}$ The recommendations for the usage of the cold therapy modalities range from 10 to $20 \mathrm{~min}$ (2-4 times a day) ${ }^{10}$ up to 45 min every 2 h. ${ }^{11}$ To date a gold standard cold therapy protocol for the acute management of musculoskeletal trauma, which includes an optimum modality with the most effective treatment protocol, has not been established.

During cold therapy the dermal layer cools first. Deeper tissue and tissue adjacent to the modality gradually decrease in temperature, as heat is transferred via conduction to rewarm the superficial skin surface close to 
the modality. ${ }^{12}$ There is a high correlation between skin surface temperature and intra-articular temperature during cold therapy. Skin surface cools in a very similar fashion to the deeper tissues, and therefore the skin surface temperature is a useful tool in measuring the effectiveness of cold therapy modalities. ${ }^{2}$ An effective cold therapy modality is one, which reduces skin surface temperatures quickly, not causing tissue damage and maintains these reduced temperatures over an extended period of time.

Many clinical studies have compared the effectiveness of cold therapy modalities on skin surface temperature of healthy participants with a single 20 min application per modality. ${ }^{1} 1314$ However, repeated application of ice and gel packs is perceived to yield a more therapeutic effect, constantly withdrawing heat energy in the attempt to reduce inflammation. ${ }^{15}$ In the postoperative setting, bandages used after knee surgery, have been shown to significantly impede the effects of cold therapy. ${ }^{16}$

We conducted a study involving cold therapy with compression on a rubber model of a human knee and compared the effectiveness of a gel pack (DonJoy-Orthopaedic Pty Ltd, Normanhurst, New South Wales, Australia) frozen at six different temperatures (1 824364860 and $72 \mathrm{~h}$ at $-20^{\circ} \mathrm{C}$ ) with an ice bag (ICE'N'EASY, Bokarina, Queensland, Australia) by measuring surface temperature. The cryotherapy was applied on top of a standardised surgical dressing. Results showed that gel packs were more effective at cooling than ice and water combinations, on average by $2.6^{\circ} \mathrm{C}$ $(\mathrm{p}<0.05){ }^{17}$

There have also been recent advances in technology to deliver cold therapy. Whole body cryotherapy (WBC) involves short exposures to air temperatures below $-100^{\circ} \mathrm{C}$ in a chambers containing two rooms. The first room contains a precooling room and then a cryogenic chamber. Cold water immersion (CWI) is a modality used by patients with rheumatic disease and athletes before and after sporting activity. A recent study compared the effect of $4 \mathrm{~min}$ of $\mathrm{WBC} 110^{\circ} \mathrm{C}$ with $\mathrm{CWI}$ at $8^{\circ}$ $\mathrm{C}$ on knee skin temperature, and if the modalities could achieve skin surface temperature required for analgesic purposes $\left(<13^{\circ} \mathrm{C}\right)$, however, neither modality were able to achieve these levels. ${ }^{18}$

Commercial devices, such as Game Ready (CoolSystems, Inc., Concord, California, USA $)^{19}$ have been used more often in the outpatient setting. This device provides intermittent pneumatic compression while delivering cryotherapy to the patient. A recent study compared the effects of Game Ready (CoolSystems, Inc., Concord, California, USA) versus ice wrap on pain in patients in the postoperative week, following subacromial decompression and rotator cuff repair. The results showed that Game Ready (CoolSystems, Inc., Concord, California, USA) was not superior over the ice wrap in reducing pain or narcotic use. ${ }^{19}$
Another study compared the cooling effects of six different modalities on quadriceps intramuscular temperature. ${ }^{20}$ These included Game Ready (CoolSystems, Inc., Concord, California, USA), ice and ice wrap. This study concluded that ice and ice wrap should be used as modalities in the treatment of injuries given that they produced intramuscular temperatures lower than that of Game Ready (CoolSystems, Inc., Concord, California, USA).

To our knowledge, however, there have been no studies, which measure the progressive effect of ice bags and gel packs on human knee skin surface temperature of healthy participants, with a surgical dressing, for more than $3 \mathrm{~h}$. While there are numerous studies, which only tested one application of each cryotherapy, the effect of multiple applications on skin surface temperature is not known.

The aim of this study, therefore, was to compare the effectiveness of gel packs and ice bags at reducing the skin surface temperature of healthy human knees, with a surgical dressing.

\section{METHODS \\ Experimental design}

This was a randomised, repeated measures crossover study, which evaluated the effectiveness of gel packs and ice bags at reducing knee skin surface temperature in healthy participants, who were wearing a surgical dressing. The South Eastern Sydney Local Health District approved this study (HREC/11/STG/231).

\section{Participants}

Nine healthy volunteers ( 8 males, 1 female) participated in this study (mean age $=23.33 \pm 5.3 \quad(20-34)$ years; height $=1.79 \pm 0.10 \mathrm{~m} \quad(1.63-1.99)$; weight $=79.57 \pm 3.21 \mathrm{~kg}$ $(49-111)$; body mass index $(\mathrm{BMI})=24.38 \pm 3.21 \mathrm{~kg} / \mathrm{m}^{2}$ (18.4-28.2)). The participants were recruited via a recruitment poster, which was placed in the University of New South Wales campus and in the St. George Hospital Orthopaedic Research Institute between March and May 2012. The sample size was determined based on a previous study which compared the cooling efficiency of cold therapy modalities on nine healthy volunteers. ${ }^{1}$ We therefore aimed to recruit a minimum of 9 participants after recruiting from a pool of 12 . Recruitment, screening and assigning of intervention was completed by MB

\section{Exclusion criteria}

All participants completed a medical questionnaire before participating in the study. Participants were excluded if they had any neurological, musculoskeletal, cardiovascular, urological and metabolic conditions, Raynaud's syndrome, cold and hot insensitivity, an open wound, or were pregnant. Twelve participants were originally recruited, two participants were excluded as they did not meet the criteria, and one participant chose not to participate (figure 1). 


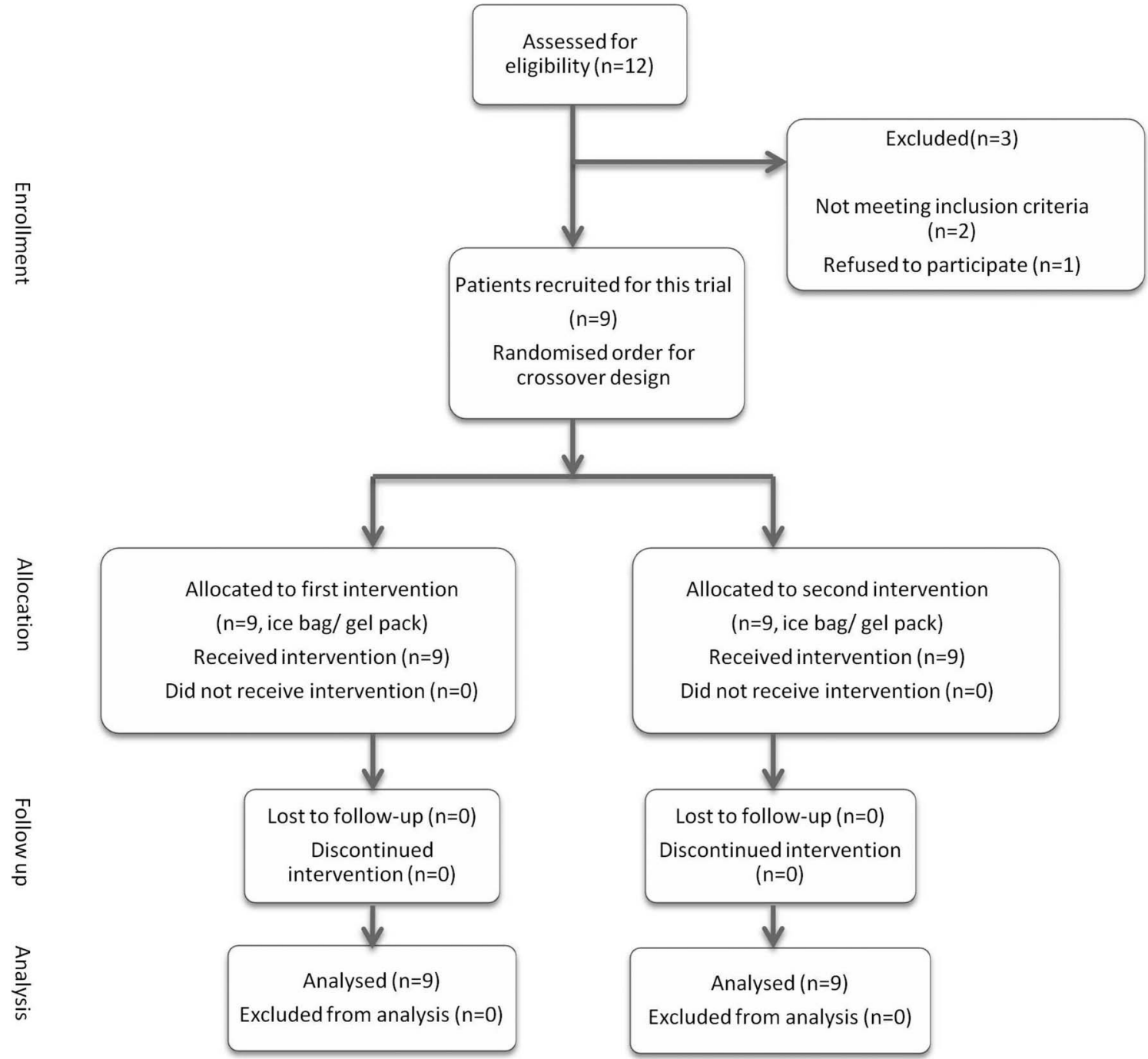

Figure 1 Flow diagram of the study showing step by step procedures of recruitment, allocation of intervention and analysis of participant's data.

\section{Consent}

All participants were informed about the test dates, experimental procedures and potential side effects of the study, such as coldness and numbness. The participants signed a consent form before participating.

\section{Equipment}

Temperature sensor

In this study the skin surface temperature was measured with a computer based temperature sensor-the USB TEMPER (Toby Technology, Shenzhen, China). The temperature sensor was placed on the participant's knee, just below the patella (kneecap) and above the tibial tuberosity (figure 2). The temperature sensor was connected via USB cable to a laptop based data acquisition unit recording skin surface temperature at $1 \mathrm{~min}$ intervals. The temperature was displayed on a laptop computer screen via software program (TEMPER V.10.3), with a resolution of $0.01{ }^{\circ} \mathrm{C}$ and a measuring range of $-40.0^{\circ} \mathrm{C}$ to $120.0^{\circ} \mathrm{C}$.
Simulated surgical dressing-(simulated for postoperative knee arthroscopy)

A standardised surgical dressing (figure 3), which comprised of: two pieces of elastic adhesive bandages $(30 \times 10 \mathrm{~cm})$ (Steroplast Ltd, Manchester M22 4TE), one anon woven combine bandage $(20 \times 20 \mathrm{~cm})$ (Multigate PTY LTD, Yennora, NSW 09-890P) and one Detex Packing Gauze $(10 \times 2 \mathrm{~m})$ (Multigate PTY LTD, Yennora, NSW 15-223).

\section{Cold therapy}

Two forms of cold therapy were tested in this study-a gel-based system and an ice-based system.

1. Gel-based cold therapy

The gel-based cold therapy was provided using DuraSoft gel inserts (DonJoy-Orthopaedic Pty Ltd, Normanhurst, New South Wales, Australia) (surface area $=\mathrm{L} \times \mathrm{W}=27 \mathrm{~cm} \times 30 \mathrm{~cm}=850 \mathrm{~cm}^{2}$ ). The inserts contained a non-toxic gel and purified water combination, making the pack malleable (figure 4). Each insert fitted 


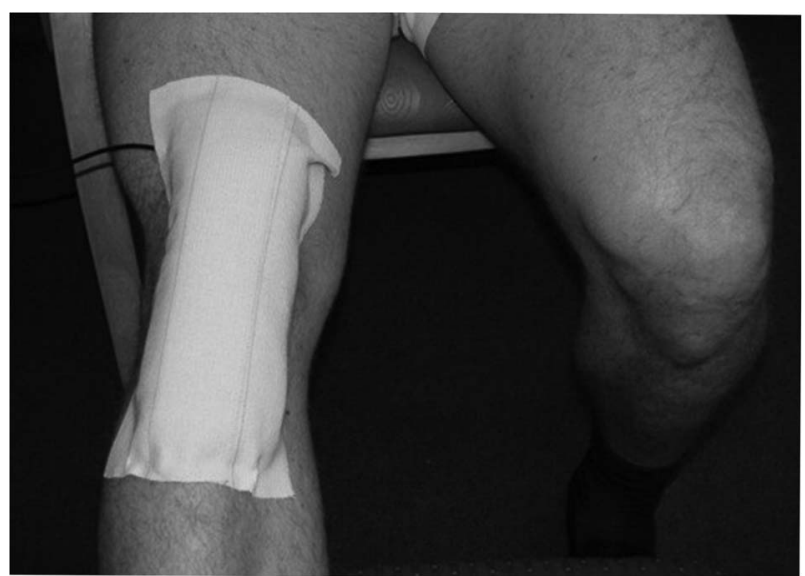

Figure 2 Photograph of surgical dressing over temperature sensor and participant's knee.

into a wrap, which had elastic straps and Velcro attached to it, in order to secure fastening. Each insert was frozen for a minimum of $36 \mathrm{~h}$, in a freezer set at $-20^{\circ} \mathrm{C}$, prior to the application, as per protocol outlined in the study by Lam et al. ${ }^{17}$

2. Ice-based cold therapy

The ice-based cold therapy was provided using ICENEASY Ice bags (Bokarina, Queensland, Australia) (approximate surface area $=411 \mathrm{~cm}^{2}$ ) and made of a velour rubber composite (figure 3 ). The ice bag was held in place by an elastic neoprene Velcro pad, which has elastic straps to attach directly onto the pad. The ice bag was filled with crushed ice, which was taken from a freezer set at $-10^{\circ} \mathrm{C}$. The ice bag when filled with ice weighed an average $1280 \mathrm{~g}$.

Both modalities are commonly used as cryotherapy today (14).

\section{Trial protocol}

Participants were required to attend two testing sessions on separate days for each of the two cold therapy modalities. Testing was completed in a room, next to the laboratory of the orthopaedic research institute at

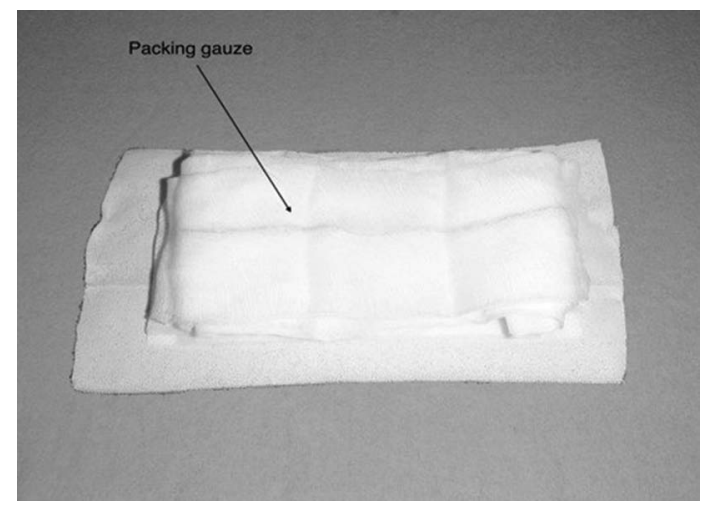

Figure 3 Photograph of packing gauze on top of woven bandage and adhesive bandage (Simulated surgical dressing).
St. George Hospital. All participants were tested between 9:00 and 14:00 and were required to arrive $30 \mathrm{~min}$ prior to testing times, to acclimatise their body temperature to room temperature. Participants were asked not to drink alcohol or exercise at least $8 \mathrm{~h}$ before the experiment began. The testing room temperature was maintained at $24^{\circ} \mathrm{C}$. The participants were asked to sit in the upright position on a chair with the non-tested leg bent, at $90^{\circ}$, and the tested leg, extended on a chair in front.

The temperature sensor was placed on the participant's extended knee-below the patella (kneecap) and above the tibial tuberosity. The temperature sensor was secured by Scotch adhesive tape (3M Scotch, Pymble, Australia). The surgical dressing was placed over the sensor (figure 4).

Each participant was to attend two sessions, which were at least 4 days a part. All participants were randomly allocated an order of sessions determined via computer-generated randomisation. A randomisation list was generated using the following software (Random Allocation Software, V.1.0.0 Isfahan University of Medical Science, Iran). Randomisation was formatted using one block, with two groups (ice/gel). Each participant was given a unique onumeric code, with 10 digits, and an allocated first session (ice/gel). Each participant was also given a random allocation of which leg was to be used (left/right) for both sessions. In the second session the participant was to be exposed to remaining modality. Randomisation was completed by PL.

Each session lasted 270 min. During each application a cold therapy modality was applied for 20 consecutive minutes. During each recovery the cold therapy modality was removed for 40 consecutive minutes (figure 4). After the second recovery there was a 10 min break, where participants were encouraged to stretch and walk around. The data recorded for each session were stored on a laptop, which remained within the confines of the laboratory.

\section{Data analysis}

Intraclass correlation coefficient (ICC) was used to analyse the intrarater reliability of the temperature sensor. The baseline temperature was calculated as the average skin surface temperature between data points 10-15 min of the baseline time segment. This baseline temperature was used to calculate the skin surface temperature reduction by subtracting end of application and recovery skin surface temperature from baseline skin surface temperature. The reductions in skin surface temperature from baseline to the completion of all applications were compared within each group using one-way analysis of variance with repeated measures and Turkey post hoc correction, between groups (gel vs ice) analysis was done using paired Student's t test.

The increases in skin surface temperature, from the beginning of every recovery to the completion of all recovery, were compared between the gel and ice groups, using a paired Student's t test. The cooling rate 


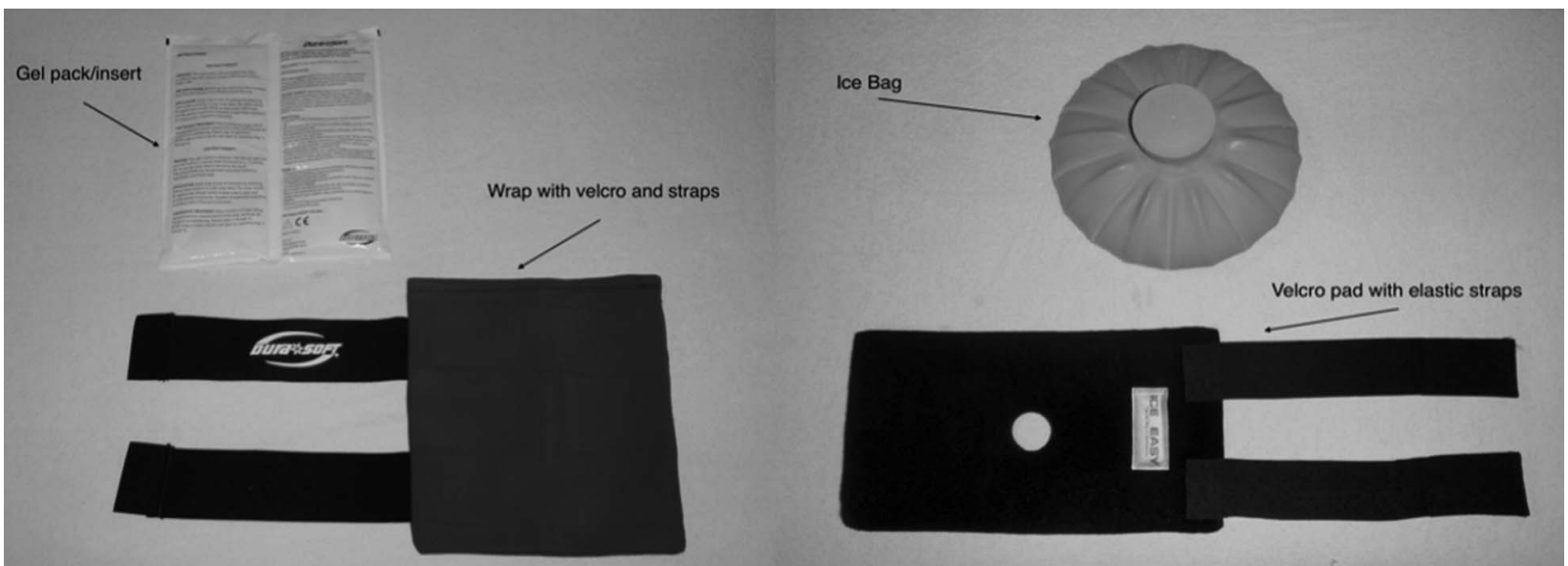

Figure 4 Photograph of gel pack with wrap (left), and photograph of ice bag with pad and straps (right).

for each application was compared between the gel and ice groups using a paired Student's t test. Results were considered statistically significant if $\mathrm{p} \leq 0.05$. The recorded data were analysed using SPSS V.20 (SPSS Inc., Chicago, Illinois, USA)/SigmaPlot V.11 (Systat Software, San Jose, California, USA).

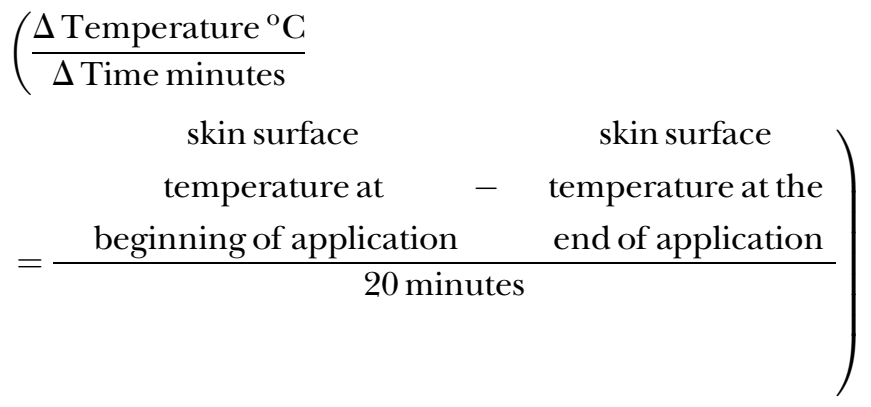

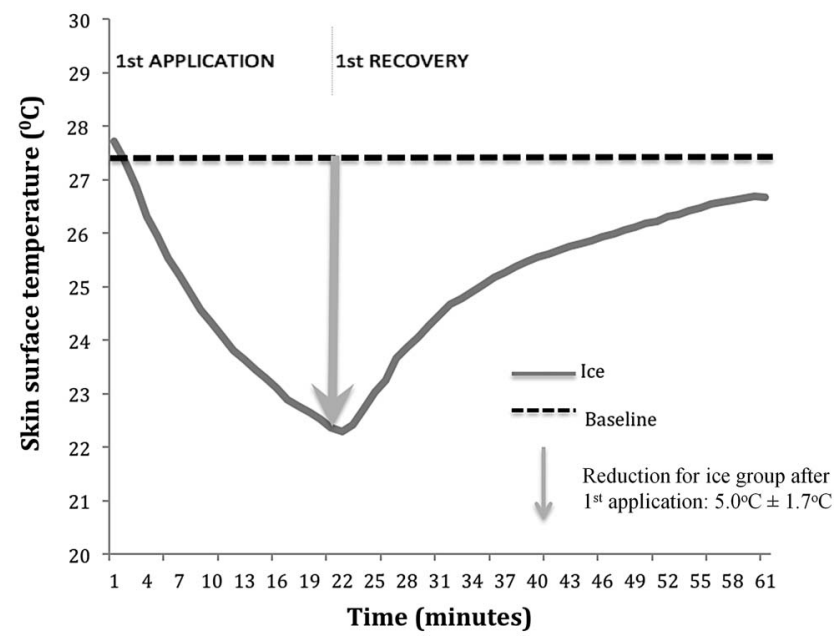

Figure 5 The effect of an ice bag on knee skin surface temperature after initial application and recovery (60 min). Values are mean $n=9$.

\section{RESULTS}

\section{Temperature sensor reliability}

The temperature sensor displayed an ICC of 1 for intradevice testing was, and a Pearson's correlation coefficient of 0.72 for the interdevice testing was $(p<0.001)$, which indicates good reliability within ${ }^{21}$ and between the sensors.

\section{Baseline temperature for gel and ice modalities}

There was no significant difference in mean skin surface temperature, prior to the initial cold therapy application (baseline temperature), between the participants in the gel pack group $\left(27.4^{\circ} \mathrm{C}\right)$ compared to the participants in the ice bag group $\left(27.4^{\circ} \mathrm{C}\right)$.

Multiple linear regression analysis showed that baseline temperature of gel pack and ice bag groups were not affected by participant's age, height, weight and BMI.

\section{Effect of the ice bag on knee skin surface temperature}

Within $5 \mathrm{~min}$ of applying the ice bag on top of the standard surgical dressing, the mean knee skin surface temperature gradually decreased from $27.4^{\circ} \mathrm{C}$ to $25.5^{\circ} \mathrm{C}$ (figure 5) at a rate of $0.38^{\circ} \mathrm{C} / \mathrm{min}\left({ }^{\circ} \mathrm{C} / \mathrm{min}\right)$. The skin surface temperature for the ice bag group then reduced at a rate of $0.29^{\circ} \mathrm{C} / \mathrm{min}$ from the $5 \mathrm{~min}$ point $\left(25.50^{\circ} \mathrm{C}\right)$ to the $10 \mathrm{~min}$ point of application $\left(24.1^{\circ} \mathrm{C}\right)$ (figure 5). From the $10 \mathrm{~min}$ point to the end of the $20 \mathrm{~min}$ of cold therapy application, the average skin surface temperature for the ice bag group then decreased from $24.1^{\circ} \mathrm{C}$ to $22.3^{\circ} \mathrm{C}$ at a rate of $0.17^{\circ} \mathrm{C}$ / $\min$ (figure 5).

At $20 \mathrm{~min}$ the ice bag was removed and the skin surface temperature increased from (figure 5) $22.3^{\circ} \mathrm{C}$ to $26.6^{\circ} \mathrm{C}$ at a rate of $0.11^{\circ} \mathrm{C} / \mathrm{min}$.

There were significant reductions $(\mathrm{p}<0.001)$ in mean skin surface temperature from baseline for the participants in the ice bag group after all four subsequent 20 min applications (table 1). 
Table 1 Effect of gel and ice modalities on skin surface temperature $\left({ }^{\circ} \mathrm{C}\right)$

\begin{tabular}{llllll}
\hline Modality & $\begin{array}{l}\text { Baseline } \\
\text { temperature }{ }^{* \circ} \mathbf{C}\end{array}$ & $\begin{array}{l}\text { First end of } \\
\text { application } \\
\text { temperature }{ }^{* \circ} \mathbf{C}\end{array}$ & $\begin{array}{l}\text { Second end of } \\
\text { application } \\
\text { temperature }{ }^{\star \circ} \mathbf{C}\end{array}$ & $\begin{array}{l}\text { Third end of } \\
\text { application } \\
\text { temperature }{ }^{* \circ} \mathbf{C}\end{array}$ & $\begin{array}{l}\text { Fourth end of } \\
\text { application } \\
\text { temperature }\end{array}$ \\
\hline ICE & 27.4 & $22.3 \pm 3.5$ & $21.0 \pm 3.5$ & $20.8 \pm 3.7$ & $20.8 \pm 3.5$ \\
GEL & 27.4 & $23.3 \pm 3.4$ & $21.9 \pm 3.6$ & $20.9 \pm 3.3$ & $20.7 \pm 2.5$ \\
\hline
\end{tabular}

*Values are mean \pm SD $n=9$

Includes baseline temperature and skin surface temperature at completion of all 20 min applications.

GEL, gel bag; ICE, ice bag.

\section{Effect of the gel pack on knee skin surface temperature}

After 5 min of applying of the first gel pack on top of a standard surgical dressing, the skin surface temperature within this group gradually decreased from $27.4^{\circ} \mathrm{C}$ to $26.4^{\circ} \mathrm{C}$ at a rate of $0.18^{\circ} \mathrm{C} / \mathrm{min}$. The mean skin surface temperature for the gel pack group then cooled at a rate of $0.32^{\circ} \mathrm{C} / \mathrm{min}$ from $5 \mathrm{~min}$ of application $\left(26.4^{\circ} \mathrm{C}\right)$ to the $10 \mathrm{~min}$ point of application $\left(24.84^{\circ} \mathrm{C}\right)$. From the $10 \mathrm{~min}$ mark to the 20 min mark, the mean knee skin surface temperature for the gel pack group decreased from $24.8^{\circ} \mathrm{C}$ to $23.3^{\circ} \mathrm{C}$ at a rate of $0.14^{\circ} \mathrm{C} / \mathrm{min}$ (figure 6).

When the gel pack was removed from the standard surgical dressing the skin surface temperature for the participants in the gel pack group gradually increased from $23.3^{\circ} \mathrm{C}$ to $26.3^{\circ} \mathrm{C}$ at a rate of $0.08^{\circ} \mathrm{C} / \mathrm{min}$ (figure 6).

At the completion of all four subsequent $20 \mathrm{~min}$ gel pack applications (figure 6), the skin surface temperature for the participants in the gel pack group had reduced significantly $(p<0.001)$ from baseline temperature table 1 .

\section{Ice versus gel}

The ice bag was more effective than the gel pack at reducing skin surface temperature of the knee of asymptomatic participants by the end of the first $20 \mathrm{~min}$ cold therapy application (figure 7), over a standard surgical

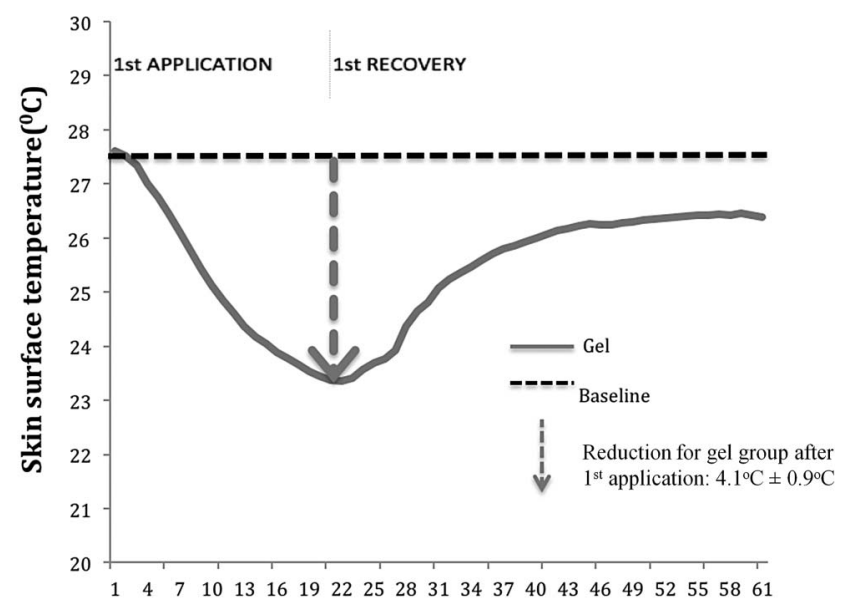

Time (minutes)

Figure 6 The effect of the gel pack on knee skin surface temperature after first application and first recovery (60 $\mathrm{min}$ ). Values are mean $n=9$. dressing $\left(5^{\circ} \mathrm{C}\right.$ vs $\left.4^{\circ} \mathrm{C}\right) \quad(\mathrm{p}<0.04)$. However the ice bag and the gel pack were equally effective at reducing skin surface temperature after the completion of all three subsequent 20 min applications table 2.

\section{The recovery period}

During the recovery periods, where the cold therapy modality was removed for $40 \mathrm{~min}$ after each application (figures 5-7), the skin surface temperature for gel pack and ice bag groups increased gradually at a similar rate (table 3).

\section{Cooling rates between the modalities}

Within the first $20 \mathrm{~min}$ application, the cooling rate for the ice bag group $\left(0.27^{\circ} \mathrm{C} / \mathrm{min}\right)$ was significantly greater $(p<0.02)$ than the cooling rate for the gel pack group $\left(0.21^{\circ} \mathrm{C} / \mathrm{min}\right)$. However, there were no significant differences in cooling rate between the ice and gel modalities in the three subsequent 20 min applications.

\section{DISCUSSION}

The study examined the effects of two forms of cold therapy on healthy human participants: an ice bag filled with crushed ice and a gel pack frozen at $-20^{\circ} \mathrm{C}$. Cold therapy was applied for 20 min every hour for $4 \mathrm{~h}$. After

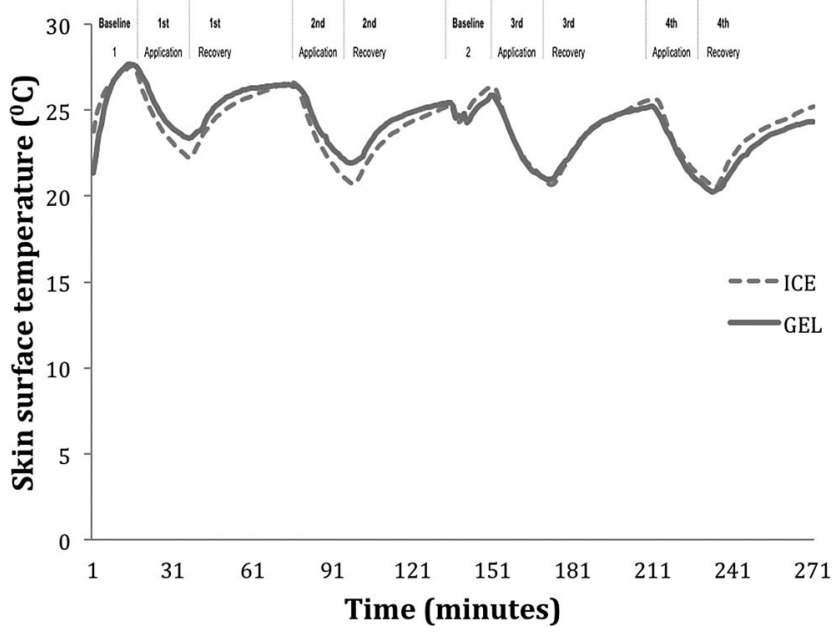

Figure 7 The effect of both gel and ice modalities on skin surface temperature in one session $(270 \mathrm{~min})$. Values are mean $n=9$. GEL, gel bag; ICE, ice bag. 
Table 2 Comparison in skin surface temperature reduction $\left({ }^{\circ} \mathrm{C}\right)$, from baseline 1 to the completion of all applications, between gel pack and ice bag groups

\begin{tabular}{|c|c|c|c|c|c|c|c|c|}
\hline Modality & $\begin{array}{l}\text { Reduction } \\
\text { from } \\
\text { baseline }{ }^{\star \circ} \mathrm{C} \\
\text { first } \\
\text { application }\end{array}$ & $\begin{array}{l}\text { Significant } \\
\text { level } \\
\text { between } \\
\text { gel and ice } \\
\text { (p value) }\end{array}$ & $\begin{array}{l}\text { Reduction } \\
\text { from } \\
\text { baseline }{ }^{\star \circ} \mathrm{C} \\
\text { second } \\
\text { application }\end{array}$ & $\begin{array}{l}\text { Significant } \\
\text { level } \\
\text { between } \\
\text { gel and ice } \\
\text { (p value) }\end{array}$ & $\begin{array}{l}\text { Reduction } \\
\text { from } \\
\text { baseline }{ }^{\star \circ} \mathrm{C} \\
\text { third } \\
\text { application }\end{array}$ & $\begin{array}{l}\text { Significant } \\
\text { level } \\
\text { Between } \\
\text { gel and ice } \\
\text { (p value) }\end{array}$ & $\begin{array}{l}\text { Reduction } \\
\text { from } \\
\text { baseline }{ }^{\star \circ} \mathrm{C} \\
\text { fouth } \\
\text { application }\end{array}$ & $\begin{array}{l}\text { Significant } \\
\text { level } \\
\text { between } \\
\text { gel and ice } \\
\text { (p value) }\end{array}$ \\
\hline & $5.0 \pm 1.7$ & $p<0.04$ & $6.4 \pm 2.6$ & $p<0.34$ & $6.5 \pm 2.1$ & $p<0.95$ & & $p<0.88$ \\
\hline GEL & $4.0 \pm 0.8$ & & $5.5 \pm 1.9$ & & $6.5 \pm 1.4$ & & $6.6 \pm 2.7$ & \\
\hline
\end{tabular}

*Values are mean \pm SD $n=9$.

the first application, the ice bag was more effective at reducing skin surface temperature, and had a greater cooling rate than the gel pack. However, in the subsequent three applications, both modalities were just as effective at reducing skin temperature from the initial baseline and both modalities cooled at similar rates. Both modalities had similar increases in skin surface temperature throughout all the recovery periods.

To our knowledge there are no other studies that have monitored multiple applications of the same cryotherapy, along with the recovery periods. The recovery period signifies the manner in which the tissue returns to physiological baseline. Using our protocol we have noticed that with each application there is an accumulative effect in reduction of skin surface temperature.

This study follows on from Lam et al, ${ }^{17}$ which assessed the effectiveness of gel packs and ice bags on a rubber knee model, and concluded that the gel pack was more effective at reducing surface temperature than an ice bag. Their study showed that after $20 \mathrm{~min}$, the ice bag had reduced surface temperature by $10.2^{\circ} \mathrm{C}$ (from $24.3^{\circ}$ $\mathrm{C})$, while the gel pack had reduced surface temperature by $13.7^{\circ} \mathrm{C}$ (from $24.4^{\circ} \mathrm{C}$ ).

In contrast, this study evaluated skin surface temperature using knees from healthy human participants. The initial temperature of the human knee was approximately $3^{\circ} \mathrm{C}$ warmer than the rubber knee model. Our study showed that after the initial $20 \mathrm{mi}$ application, there was a reduction in skin surface temperature of $5^{\circ} \mathrm{C}$ and $4^{\circ} \mathrm{C}$, respectively, for the participants in the ice bag and gel pack groups. In comparison, the knee model study $^{17}$ showed that after initial $20 \mathrm{~min}$ of application there was a reduction in surface temperature of $10.2^{\circ} \mathrm{C}$ and $13.7^{\circ} \mathrm{C}$, respectively, for the ice bag (with ice shavings and water) and the gel pack (frozen at $-20^{\circ} \mathrm{C}$ for $36 \mathrm{~h}$ ). The reason for the differences between the effects of the cold therapy devices on the human leg, compared to the rubber model can be explained by the rewarming of the superficial area by the deeper tissue in the human leg.

Previous studies have assessed the effectiveness ${ }^{2}{ }^{14}$ and efficiency ${ }^{1}$ of ice packs, ice bags, gel packs, frozen peas and other modalities on healthy human participants with a single application and in sessions up to $2 \mathrm{~h}$. Ice has consistently been shown to be more effective ${ }^{214}$ and more efficient ${ }^{1}$ than gel at reducing skin surface temperature in healthy human participants. A possible explanation for the ice bag's effectiveness during a single application might be its ability to absorb more heat as it goes through a state of physical change (melts from ice to water). Gel has a much lower preapplication temperature but does not melt. Fourier's law of thermal conductivity states the importance of a steep temperature difference between two objects, in order to facilitate heat transfer. ${ }^{22}$ In theory then, a cooler gel pack should lower skin surface temperature more effectively than the ice bag, but this law does not take into account the energy needed for phase change, which occurs with ice. $^{14}$

Studies have shown that secondary tissue damage after surgery $^{23}$ and nerve conduction velocity ${ }^{4}$ can be reduced, if the skin temperature is maintained between $10^{\circ} \mathrm{C}$ and $15^{\circ} \mathrm{C}$ for $10-20 \mathrm{~min}$. Our results indicate that after $4 \mathrm{~h}$ with our protocol of applications every hour, the skin surface temperature of healthy participants in the gel and ice groups were $20.8^{\circ} \mathrm{C}$ and $20.7^{\circ} \mathrm{C}$, with a

Table 3 Comparison of increase in skin surface temperature $\left({ }^{\circ} \mathrm{C}\right)$ throughout all recoveries between gel pack and ice bag groups

\begin{tabular}{|c|c|c|c|c|c|c|c|c|}
\hline Modality & $\begin{array}{l}\text { First } \\
\text { recovery: } \\
\text { rise }{ }^{\star \circ} \mathrm{C}\end{array}$ & $\begin{array}{l}\text { Significant } \\
\text { level } \\
\text { between gel } \\
\text { and ice } \\
\text { ( } p \text { value) }\end{array}$ & $\begin{array}{l}\text { Second } \\
\text { recovery: } \\
\text { rise }{ }^{\star \circ} \mathrm{C}\end{array}$ & $\begin{array}{l}\text { Significant } \\
\text { level } \\
\text { between gel } \\
\text { and ice } \\
\text { ( } p \text { value) }\end{array}$ & $\begin{array}{l}\text { Third } \\
\text { recovery: } \\
\text { rise }{ }^{\star \circ} \mathrm{C}\end{array}$ & $\begin{array}{l}\text { Significant } \\
\text { level } \\
\text { between gel } \\
\text { and ice } \\
\text { (p value) }\end{array}$ & $\begin{array}{l}\text { Fourth } \\
\text { recovery: } \\
\text { rise }{ }^{\star \circ} \mathrm{C}\end{array}$ & $\begin{array}{l}\text { Significant } \\
\text { level } \\
\text { between gel } \\
\text { and ice } \\
\text { ( } p \text { value) }\end{array}$ \\
\hline ICE & $4.3 \pm 0.7$ & $p<0.1$ & $3.9 \pm 2.2$ & $p<0.4$ & $4.8 \pm 1.3$ & $p<0.17$ & $4.1 \pm 1.5$ & $p<0.71$ \\
\hline GEL & $3.0 \pm 1.8$ & & $3.2 \pm 0.9$ & & $4.2 \pm 0.9$ & & $3.5 \pm 1.0$ & \\
\hline
\end{tabular}

*Values are mean \pm SD $n=9$. 
fall in temperature of $6.6^{\circ} \mathrm{C}$ and $6.5^{\circ} \mathrm{C}$, respectively. It should be noted that bandages have also been shown to significantly impede the cooling ability of the cold therapy on the knee. ${ }^{16}$ There are no studies to our knowledge that compare the continuous cooling effect of gel and ice modalities, using our protocol, with the inclusion of a surgical dressing. Thus an application time longer than $20 \mathrm{~min}$ is perhaps necessary when using our protocol, for gel packs and ice bags to achieve a therapeutic effect in the postoperative knee. However, this might increase the risk of cold injury.

The limitations of this study included that the sample size was relatively small comprising of only nine participants. There was not an even amount of male and female participants ( 8 males and 1 female). A test to assess the adipose thickness of the knees of the participants was not included. We only tested two cold therapy modalities. These results may not apply to other types of dressing used following orthopaedic surgery to the knee. Another important factor that must be addressed is that the modalities had differed in surface areas. Owing to the large difference in surface area of the two modalities, it could effect the reduction in skin surface temperature.

The strengths of the study were that the experiment involved healthy participants. Skin surface temperature was monitored and sampled every minute during the entire experiment. The experiment took place in a temperature-controlled environment. A surgical dressing applied over the knee was used to replicate a surgical dressing possibly used after a knee arthroscopy. This is the only study that tested the progressive effect of ice bag and gel pack on the skin surface temperature of healthy participants, with a standard surgical dressing.

\section{CONCLUSION}

The ice bag was more effective than the gel pack at reducing knee skin surface temperature, in the first application of $20 \mathrm{~min}$. Both ice bags and gel packs, however, were just as effective at reducing skin temperature and maintaining these lower temperatures over the $4 \mathrm{~h}$ period. A cold therapy protocol, which includes an application time of $20 \mathrm{~min}$ (every hour), was not sufficient for gel packs and ice bags to reduce skin surface temperature to therapeutic levels.

Contributors MB planned the study, recruited participants, conducted the cold therapy testing sessions, assisted with statistics and wrote the manuscript. PL conducted the statistics and assisted with cold therapy testing sessions. GACM planned the study and corrected the manuscript.

\section{Competing interests None declared.}

Patient consent Obtained.

Ethics approval New South Wales.

Provenance and peer review Not commissioned; externally peer reviewed.

Data sharing statement No additional data are available.
Open Access This is an Open Access article distributed in accordance with the Creative Commons Attribution Non Commercial (CC BY-NC 4.0) license, which permits others to distribute, remix, adapt, build upon this work noncommercially, and license their derivative works on different terms, provided the original work is properly cited and the use is non-commercial. See: http:// creativecommons.org/licenses/by-nc/4.0/

\section{REFERENCES}

1. Kennet J, Hardaker N, Hobbs S, et al. Cooling efficiency of 4 common cryotherapeutic agents. J Athl Train 2007;42:343-8.

2. Kanlayanaphotporn R, Janwantanakul P. Comparison of skin surface temperature during the application of various cryotherapy modalities. Arch Phys Med Rehabil 2005;86:1411-15.

3. Cina-Tschumi B. [Evidence-based impact of cryotherapy on postoperative pain, swelling, drainage and tolerance after orthopedic surgery]. Pflege 2007;20:258-67.

4. Algafly AA, George KP. The effect of cryotherapy on nerve conduction velocity, pain threshold and pain tolerance. $\mathrm{Br} J$ Sports Med 2007;41:365-9.

5. Healy WL, Seidman J, Pfeifer BA, et al. Cold compressive dressing after total knee arthroplasty. Clin Orthop Relat Res 1994;299:143.

6. Saito $\mathrm{N}$, Horiuchi $\mathrm{H}$, Kobayashi $\mathrm{S}$, et al. Continuous local cooling for pain relief following total hip arthroplasty. J Arthroplasty 2004;19:334-7.

7. Bleakley CM, McDonough SM, MacAuley DC, Cryotherapy for acute ankle sprains: a randomised controlled study of two different icing protocols. Br J Sports Med 2006;40:700-5

8. Konrath GA, Lock T, Goitz HT, et al. The use of cold therapy after anterior cruciate ligament reconstruction: a prospective, randomized study and literature review. Am J Sports Med 1996;24:629-33.

9. Holmström A, Härdin BC. Cryo/Cuff compared to epidural anesthesia after knee unicompartmental arthroplasty: a prospective, randomized, and controlled study of 60 patients with a 6 -week follow-up. J Arthroplasty 2005;20:316-21.

10. Bleakley C, McDonough S, MacAuley D. The use of ice in the treatment of acute soft-tissue injury: a systematic review of randomized controlled trials. Am J Sports Med 2004;32:251-61.

11. Mac Auley DC. Ice therapy: how good is the evidence. Int J Sports Med 2001;22:379-84.

12. Enwemeka CS, Allen C, Avila $\mathrm{P}$, et al. Soft tissue thermodynamics before, during, and after cold pack therapy. Med Sci Sports Exerc 2002;34:45-50.

13. Janwantanakul $P$. The effect of quantity of ice and size of contact area on ice pack/skin interface temperature. Physiotherapy 2009;95:120-5.

14. Merrick MA, Jutte LS, Smith ME. Cold modalities with different thermodynamic properties produce different surface and intramuscular temperatures. J Athl Train 2003;38:28-33.

15. Bleakley CM, O'Connor S, Tully MA, et al. The PRICE study (Protection Rest Ice Compression Elevation): design of a randomised controlled trial comparing standard versus cryokinetic ice applications in the management of acute ankle sprain [ISRCTN13903946]. BMC Musculoskelet Disord 2007;8:125.

16. Ibrahim T, Ong SM, Saint Clair Taylor GJ. The effects of different dressings on the skin temperature of the knee during cryotherapy. Knee 2005;12:21-3.

17. Lam P, Kelly M, Murrell G. Ice vs. Gel, best strategies to reduce skin temperature? J Sci Med Sport 2010;13:e50.

18. Costello J, Donnelly AE, Karki A, et al. Effects of whole body cryotherapy and cold water immersion on knee skin temperature. Int J Sports Med 2014;35:35-40.

19. Kraeutler MJ, Reynolds KA, Long C, et al. Compressive cryotherapy versus ice-a prospective, randomized study on postoperative pain in patients undergoing arthroscopic rotator cuff repair or subacromial decompression. J Shoulder Elbow Surg 2015;24:854-9.

20. Simonson JC. Ice and ace wrap and Game Ready (RTM) in decreasing quadriceps temperature, Masters thesis, North Dakota State University, 2014, p.1-75.

21. Fleiss JL, Nee JCM, Landis JR. Large sample variance of kappa in the case of different sets of raters. Psychol Bull 1979;86:974-7.

22. Fourier J. The analytical theory of heat, New York: Dover Publishing, 1955:84-6.

23. Greenstein G. Therapeutic efficacy of cold therapy after intraoral surgical procedures: a literature review. J Periodontol 2007;78:790-800. 